\title{
Activists seek retirement home for chimps
}

Washington. Animal rights groups in the United States have proposed the setting up of a National Chimpanzee Sanctuary, paid for jointly by the National Institutes of Health (NIH) and charitable contributions, to enable the country's estimated 1,500 research chimpanzees to 'retire' in comfort once they are no longer needed - if they are needed at all.

The groups have made the proposal as the National Research Council (NRC) embarks, at the request of NIH, on a study of what to do with the chimpanzees, which can live to the age of 55 . Boosted in number by a breeding programme which the NIH started in 1986, many hundreds of the chimps are no longer used for research.

The chimps cannot be returned to the wild, and public opinion would be against putting them down. So they continue to languish in single cages in half-a-dozen centres.
Directly or indirectly, the NIH pays most of the $\$ 10$ million a year that they cost to keep.

A panel of the NRC, chaired by Dani Bolognesi, director of the Duke Center for AIDS Research, North Carolina, has been asked to set out options for what to do with the chimps and who should pay for their care. At an initial public meeting of the panel in Washington last week, hopes were high that animal rights groups and biomedical researchers can, for once, find common ground.

But their unlikely alliance may founder on the rock of finance. One activist - Christine Stevens of the Animal Welfare Institute — suggests that NIH should set aside $\$ 100$ million to care for the animals indefinitely. NIH managers accept some responsibility for long-term care, but want to reduce their existing costs.

Michael McGehee, a lobbyist for animal

\section{Russian institutes fear lost deposits}

Moscow. Russia's presidential election campaign has brought relief to cashstarved government research laboratories. Following a promise by President Boris Yeltsin, all sums owed by the state have been transferred to the banks acting for research institutes and laboratories.

But just as these clouds over Russian science were beginning to disappear, a new misfortune has arrived. Most scientific institutions have been keeping their money in small commercial banks, as larger banks have been reluctant to handle the relatively modest sums involved. But one of these has now stopped paying out on deposits, giving rise to fears that substantial research funds may be lost.

A number of institutes of the Russian Academy of Sciences had deposited their funds with the Balchug bank in Moscow. Last month, for example, both the Russian Ministry of Science and Technological Policy and the Russian Foundation for Fundamental Research transferred to the Balchug bank funds for several institutes, including the Institute of Molecular Biology and the Institute of Gene Biology.

But when the institutes started sending payment orders to their bank, even though requests for small transfers were processed normally, it soon became apparent that others were being ignored. To make matters worse, many of the institutes used their accounts with the bank to hold money allocated for the national scientific programmes, due to be distributed to a range of laboratories.

The sum of 750 million rubles
(US $\$ 150,000)$ deposited by the Microbiology Institute, for example, includes 400 million rubles allocated to the 'Human Genome' project and more than 100 million rubles allocated to a national project on the 'material base for biology studies development'.

As a result, dozens of Russian research institutions have been unable to withdraw money allocated to them by the Russian government. "As soon as we found out that the Balchug bank was not processing our payment orders, even though it did not say it was bankrupt, we informed both the Ministry of Science and Technological Policy and the Central Bank of Russia, which is meant to have special reserve insurance funds for such occasions," says Alexander Zelenin of the Molecular Biology Institute.

"But we did not get a reply, and have had to contact another bank, Menatep, which is large and reliable, but inconvenient for us in many ways." Zelenin hopes that, after the elections, the authorities will find time to sort out these problems and to return to scientists the money given by the government during the election campaign.

According to Oleg Baranov, vice-president of the Balchug bank, its current difficulties are the result of loans not being repaid in the light of economic uncertainties over the forthcoming election. Its major debtor is a joint stock company, Bulchug, which links together about a dozen commercial operations and has withdrawn its support for the bank - even though it is its main shareholder.

Carl Levitin rights groups, says that legislation to establish their proposed sanctuary will be introduced in Congress next month. The proposal would require the government to match charitable donations to run the sanctuary of up to $\$ 5$ million a year. The legislation's chances are slim, but a cost-shared sanctuary remains the most likely destination for 'retired' research chimpanzees.

The panel was told that successful sanctuaries exist in Africa to look after orphan chimpanzees. According to Don Buford, chief executive of the Jane Goodall Institute, which runs them, they could serve as a useful model for US sanctuaries.

But he warns that the return to Africa of US research chimpanzees, many of which are infected or potentially infected with diseases such as HIV and hepatitis B, would be "fiercely opposed" by African governments. The infectious diseases will also complicate

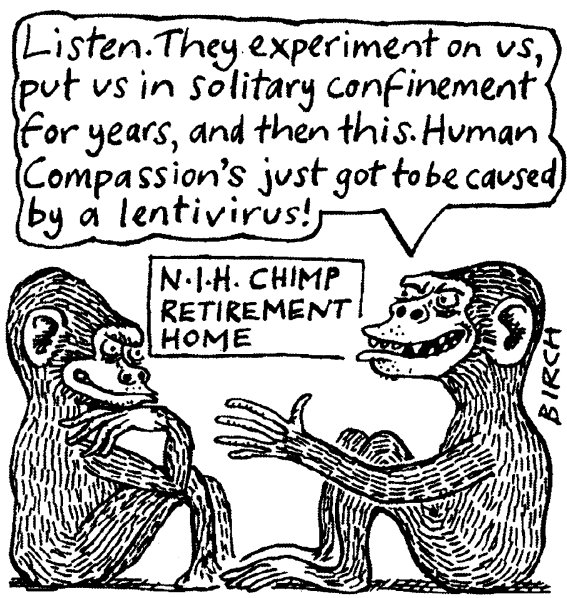

any solution which releases the animals from solitary confinement in laboratory cages.

Returning the chimpanzees to their natural habitat is also out of the question; experts agree that they would not survive. Killing them is not illegal, as the chimpanzee is not listed as an endangered species in the United States. But, as Louis Sibal, director of the office of laboratory animal research at NIH, says, "there is an unwritten assumption that euthanasia is not acceptable."

The usefulness of the chimpanzees for AIDS research has not matched the expectations of the NIH when it began its breeding programme. The result is a growing surplus of ageing animals, which either the NIH or the public will have to care for.

The first task of the panel will be to define the issue adequately: no-one really knows the precise size of the surplus, or its cost. (The $\$ 10$-million estimate is based on the common assumption that the animals cost between $\$ 15$ and $\$ 20$ a day to care for in their current laboratory environment). It will issue its report later in the year.

Colin Macilwain 